$\xi=-1$

\title{
The Influence of Socially Responsible-HRM Practices on Retaining Talents
}

\author{
Zainab Ali Rawshdeh ${ }^{* 1}$, Zaher Zain ${ }^{2}$, Ida Rosnita Ismail ${ }^{3}$ \\ UKM-Graduate School of Bussiness, Universiti Kebangsaan Malaysia \\ *Corresponding author E-mail: zeinab10@yahoo.com
}

\begin{abstract}
Corporate Social Responsibility (CSR) and Talent Management (TM) are at pivotal point in their development. However, the absence of rigorous studies that explore the relationship between Talent Retention and dimensions of CSR in the literature is surprising. Thus, the attempt of current research is to address this gap in the literature, by studying the effect of Socially Responsible Human Resource Management (HRM) practices on talent retention. And to contribute to the body of the literature by providing further insights about the importance of CSR to TM. Also, by adopting Socially Responsible HRM practices as different CSR practices that can affect organizational retention through different processes and impact stakeholders in different way. Furthermore, it answers recent calls for additional research about the impact of CSR on retaining talents, and on how integrating CSR into the culture of the organization could provide the organization with valuable conception in the talent retention.
\end{abstract}

Keywords: (Corporate Social Responsibility (CSR); Socially Responsible HRM; Talent Retention; Talent Management (TM).

\section{Introduction}

Since McKinsey \& Co.’s (1997) study on "war for talent", community in general and business organizations in particular widely acknowledged Talent management (TM) and retention among the most important factors for organizational competitive advantage and future success $(1,2)$. However, attracting talents alone is not enough; there is a need to a planned strategy for managing talents, attached with processes for properly benefit the talented abilities and retain them (3). As (4) claimed that its becoming harder to hire and retain talents. Moreover, the talents scarcity will remain essential challenge for organizations (5). Furthermore, studies showed that in addition to the direct financial costs of talent turnover that is becoming around $200 \%$ of their annual salary and sometimes even more $(6,7)$, talent turnover can lead to losing strategic tacit knowledge, work disruptions, expertise/knowledge loss, and even contagion to other valued employees to leave the organization (8).

Previous literature about varied factors affect talent retention showed that organizations are increasingly benefit employer branding (9), as well as pay, physical working conditions, promotion , relationship with others/superiors, and recognition (10), in addition to the challenging and interesting job $(7,11)$ in talent attraction and retention. However, despite the importance of talent retention issue and the interest paid on the TM practice, some important factors which influence the retention of talented employees still need to be explored. Furthermore, talented individuals who by fostering innovation, creativity and productivity they confirm the business sustainability (12), are a major concern to organization leaders $(13,14)$. However, their needs, preferences, and expectations are not fully explored $(15,16)$, therefore, the focus of this research is on the individual talent perspective.
Corporate social responsibility (CSR) is one of the top trends affecting the workplace during the previous three decades (17). Furthermore, a new school of thought advocated that there is a strong evidence that organization's CSR initiatives are increasingly becoming a secret weapon and a key component to attract and retain talents(18-20). CSR can be play a significant role in helping organization to improve talent retention (19), providing that high salaries and promotions are less of a feature in today's climate, and as the coming talent generation are looking for organization with strong value (21).However, from reviewing the literature there is a body of literature dealing with the influence of CSR on employer attractiveness (e.g. $(22,23))$. Nevertheless, retention of talent has not received much attention. Research in this area are scarce.

Accordingly, this study will extend the current literature by exploring how Socially Responsible HRM practices are related to talent retention. And it will particularly make these contributions to the existing research. First, despite the great importance of CSR issue for organizations and society in general, little is known about the micro-foundations of CSR (24), and the employee 's voice has been noticeably absent (25). By studying the effect of Socially Responsible HRM on talent retention form employee perspective the current study will contribute to the body of the knowledge by addressing this gap and answer to calls for researches on how CSR affects individuals level (26). Second, CSR and TM are at pivotal points in their development. However, the absence of rigorous studies that uncover the relationship between talent retention and dimension of CSR in the literature is surprising. Thus, attempt of this study is to address this gap and to contribute to the body of knowledge, by studying the effect of Socially Responsible HRM practices, as different CSR practices have different influences on stakeholders and impact organizational retention through different processes. Moreover, it answers the calls of $(27,28)$ for additional research about the impact of CSR on retaining talents, and on how integrating CSR into the culture 
of the organizational could be effective in providing the organizations with valuable conception in talent retention..

\section{Literature Review}

\subsection{Talent Retention}

Talent retention is considered as important factor that triggers organization success, growth, survival, and performance in the current world economic situation and competitive market place (29). Considering talent retention as a part of organization culture makes it effective(30). Organizations recognized that a strategic mechanism in talent retention is a key driver to sustainable competitive advantage, and that as managers are responsible about their budget they are accountable for increasing their talented employees as argued in the McKinsey and Company authors book The War for Talent in 2000.The wide literature provided several definitions for talent retention $(31,32)$. Referring to (33) definition, talent retention is about the employer efforts in keeping the desirable employees in order to meet business objectives.

In reviewing the literature about different factors impacting talent retention, many studies focused on employer branding, showing that organizations are ever more looking to benefit branding in attracting and retaining talent (9). Hence, (34), assumed that when employees attracted by brand equity they are more likely to retain with the organization. Also, (35) model linked employer branding to talent attraction and retention. On the other hand, (36) study differentiated attitudes to branding from attraction to retention and grouped them in order of importance.

On the other hand, (37) study mentioned 10 factors that affect retaining talented employees which are: fitting between talent employees - corporate culture, joint -responsibility and attachment, training, skills development, competences matching positions, matching the motivation with the talent's need, immediate financial bonuses, engaging talents in corporate solving problem process, and togetherness sense. Furthermore, (11) assured that the interesting and challenging job that can lead to real satisfaction, not the remuneration level keeps talent. Moreover, (10) claimed that pay, promotion, relationship with others/superiors, physical working conditions, and recognition were the major factors that impact the effectiveness of retaining talent in any organization.

\subsection{Corporate Social Responsibility (CSR)}

The importance of business social responsibility increased during the previous three decades. This demand for CSR emerged from both business organizations in order to increase profitability and to provide a positive public image, as well as, from community as institutional regulation or a groundswell of public $(38,39)$. The previous literature provided diverse definitions for CSR. Referring to a well-known definition by (40), CSR is concerned about dealing with all of the firm stakeholders in an ethical way and, rising living standards for people inside and outside the firm. Previous research investigated the organizations CSR practices and their effect on both internal and external stakeholders (41). Studies on external stakeholders as, consumers (42) and, investors (43). On the other hand, studies on internal stakeholders as, employees (44, 45) and managers (46).

\subsection{Socially Responsible HRM (SRHRM)}

Recently, researchers have recognised that an increased number of organisations are now using HRM as a key driver to enhance their business performance in social responsibility and to get their managers ready for social, and ethical issues (47, 48). Literature showed the pivotal role that HRM plays in the implementation of sustainable strategy and CSR initiatives in organisations $(21,49)$. In emerging HRM literature, the CSR-HRM nexus has been labelled under different terms such as socially conscious HRM (50), sustainable HRM (51), and ethical HRM (52). All these terms indicate the accountability of HRM function in delivering those particular HR practices that support organisation-wide CSR policy. Accordingly, combining CSR with HRM advances the current knowledge foundation of the HRM literature, as well as, it is importance because CSR has increasingly become significant to organizations.

Considering the importance of employees in CSR-HRM framework, (53) have proposed the concept of socially responsible HRM (i.e., SRHRM), with a notion that SRHRM is as effective as other progressive HRM systems in strategic development of organizations. (54) referred to socially responsible HRM as CSR policies and practices directed at employees to underpin the effectiveness of the implementation of CSR. SRHRM goes further than enhancing the working conditions for employees and providing them with extra payment and may include the recruitment and retention of socially responsible employees, considering employees' social contributions in promotion, performance appraisal, and remuneration, and providing them with social issues training, (53, 55). Consequently, the influence of SRHRM on employee work behaviors go above and beyond the effect of general HRM, furthermore, this influence can be among different mediation paths and moderation conditions from that for general HRM.

\subsection{Talent \& CSR}

CSR can create a win-win position for corporations as a positive source of competitive advantage $(56,57)$, as well as an effective strategy for retaining, motivating, and attracting talent $(18,58)$. Hence, organizations can lever TM using a planned approach which improve the effectiveness of CSR (59) Among the initial studies to explore the influence of CSR on talent attraction was (23) research. Finding from (20) study shows that organization with high responsible leadership get the full benefit of retain talent only through mediating effect of organization pride and satisfaction.

\section{Conceptual Model}

Drawing on the above studies that has been conducted by reviewing the literature for the purpose of this study. Figure 1 shows conceptual model of the relationships among study variables. As shown in the figure1, Socially Responsible-HRM Practices are directly related to talent retention.

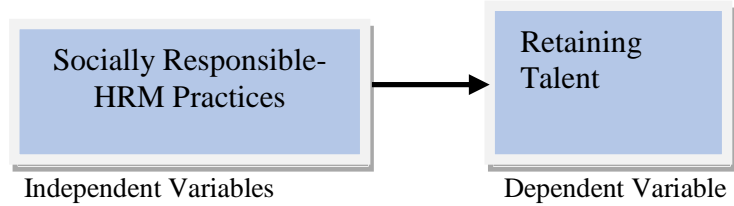

Fig. 1: Conceptual Model

Based on the above, the following hypothesis can be stated: Hypothesis 1: There is a direct positive relationship between Socially Responsible HRM practices and Talent Retention.

\section{Conclusion}

The literature review that conducted in this study on the relations between CSR and TM found that research on the relationship between talent retention and dimensions of CSR are limited. Thus, the purpose of this study is to provide additional insights into the value of CSR to TM by studying the effect of socially responsible HRM practices on talent retention.

A questionnaire that include the variables stated in this model can be employed to empirically teste it. Accordingly, the effect of Socially Responsible HRM practices on talent retention can be 
identified, in order to help decision makers to focus more on CSR practices that affect talent retention.

However, it deserves to mention that due to time limitation, accessible literature has been used for this study. Therefore, the conceptual model can be strengthened by incorporating additional related literature.

\section{References}

[1] Collings DG, Mellahi K. Strategic talent management: A review and research agenda. Human resource management review. 2009;19(4):304-13.

[2] Rose RC, Kumar N. The influence of organizational and human resource management strategies on performance. Performance improvement. 2006;45(4):18-24.

[3] McDonnell A. Still fighting the "war for talent"? Bridging the science versus practice gap. Journal of Business and Psychology. 2011;26(2):169-73.

[4] Ployhart RE. Staffing in the 21st century: New challenges and strategic opportunities. Journal of management. 2006;32(6):868-97.

[5] Al Ariss A, Vassilopoulou J, Özbilgin MF, Game A. Understanding career experiences of skilled minority ethnic workers in France and Germany. The International Journal of Human Resource Management. 2013;24(6):1236-56.

[6] Cascio W, Boudreau J. Investing in people: Financial impact of human resource initiatives: Ft Press; 2010.

[7] Mihelic KK, Plankar K, editors. The growing importance of talen management. An Enterprise Odyssey International Conference Proceedings; 2010: University of Zagreb, Faculty of Economics and Business.

[8] Allen DG, Bryant PC, Vardaman JM. Retaining talent: Replacing misconceptions with evidence-based strategies. The Academy of Management Perspectives. 2010;24(2):48-64.

[9] Backhaus K, Tikoo S. Conceptualizing and researching employer branding. Career development international. 2004;9(5):501-17.

[10] Ibidunni S, Osibanjo O, Adeniji A, Salau OP, Falola H. Talent retention and organizational performance: A competitive positioning in Nigerian banking sector. Periodica Polytechnica Social and Management Sciences. 2016;24(1):1.

[11] Carleton K. How to motivate and retain knowledge workers in organizations: A review of the literature. International Journal of Management. 2011;28(2):459.

[12] Baharin I, Abdullah A. Sustainable business in Malaysia: The need for talent ecosystem. International Journal of Basic and Applied Sciences. 2011;11(4):30-3.

[13] Bartlett CA, Ghoshal S. Building competitive advantage through people. MIT Sloan management review. 2002;43(2):34.

[14] Glen C. Fostering talent opportunity: getting past first-base. Strategic Direction. 2007;23(10):3-5.

[15] Tansley C. What do we mean by the term "talent" in talent management? Industrial and commercial training. 2011;43(5):266 74.

[16] Thunnissen M, Boselie P, Fruytier B. Talent management and the relevance of context: Towards a pluralistic approach. Human Resource Management Review. 2013;23(4):326-36.

[17] Below S. New year, new workplace! SIOP announces top 10 workplace trends for 2015. Society for Industrial and Organizational Psychology. 2014.

[18] Camilleri MA. Corporate sustainability and responsibility toward education. Journal of Global Responsibility. 2016;7(1):56-71.

[19] Farndale E, Scullion H, Sparrow P. The role of the corporate HR function in global talent management. Journal of world business. 2010;45(2):161-8

[20] Tymon Jr WG, Stumpf SA, Doh JP. Exploring talent managemen in India: The neglected role of intrinsic rewards. Journal of World Business. 2010;45(2):109-21

[21] Manroop L, Singh P, Ezzedeen S. Human Resource Systems and Ethical Climates: A Resource- Based Perspective. Human resource management. 2014;53(5):795-816.

[22] Backhaus KB, Stone BA, Heiner K. Exploringthe relationship between corporate social performance and employer attractiveness. Business \& Society. 2002;41(3):292-318.

[23] Greening DW, Turban DB. Corporate social performance as a competitive advantage in attracting a quality workforce. Business \& Society. 2000;39(3):254-80.
[24] Aguinis H, Glavas A. What we know and don't know about corporate social responsibility: A review and research agenda. Journal of management. 2012;38(4):932-68.

[25] O'Connor A, Paskewitz EA, Jorgenson DA, Rick JM. How changes in work structure influence employees' perceptions of CSR millionaire managers and locked-out laborers. Journal of Applied Communication Research. 2016;44(1):40-59.

[26] Evans WR, Davis WD, Frink DD. An examination of employee reactions to perceived corporate citizenship. Journal of Applied Social Psychology. 2011;41(4):938-64

[27] Heinrich E. Overcoming Regional Retention Issues: How Some Michigan Organizations Use CSR to Attract and Engage Top Talent. Corporate Social Responsibility, Sustainability, and Ethica Public Relations: Strengthening Synergies with Human Resources: Emerald Publishing Limited; 2017. p. 89-122.

[28] Story J, Castanheira F, Hartig S. Corporate social responsibility and organizational attractiveness: implications for talent management. Social Responsibility Journal. 2016;12(3):484-505.

[29] Wheelock D. Cultivating top Talent at Mercer. Training and Development. 2010(44):138-9.

[30] Brundage H kM. Retaining Top Talent. J Account. 2010;209(5).

[31] Creelman D. Return on investment in talent management: Measures you can put to work right now. Human Capital Institute. 2004;2121:01

[32] D'Annunzio-Green N. Managing the talent management pipeline: Towards a greater understanding of senior managers' perspectives in the hospitality and tourism sector. International Journal of Contemporary Hospitality Management. 2008;20(7):807-19.

[33] Frank FD, Finnegan RP, Taylor CR. The race for talent: retaining and engaging workers in the 21 st century. People and Strategy. 2004;27(3):12

[34] Supornpraditchai T, Miller K, Lings IN, Jonmundsson J, editors. Employee-based brand equity: antecedents and consequences. Australian and New Zealand Marketing Academy Conference; 2007: Otago University.

[35] Botha A, Bussin M, De Swardt L. An employer brand predictive model for talent attraction and retention. SA Journal of Human Resource Management. 2011;9(1):1-12.

[36] K. Ito J, M. Brotheridge C, McFarland K. Examining how preferences for employer branding attributes differ from entry to exit and how they relate to commitment, satisfaction, and retention. Career Development International. 2013;18(7):732-52.

[37] St AD. Ten Ways to Retain High-Performance Employees. Canadian Manager. 2000;25(2):21-2.

[38] Bertels S, Peloza J. Running just to stand still? Managing CSR reputation in an era of ratcheting expectations. Corporate Reputation Review. 2008;11(1):56-72.

[39] Quazi A, Nejati M, Amran A. The CSR journey: looking through the evolutionary lens. Corporate Social Responsibility and Sustainability: Contemporary Perspectives. 2015.

[40] Hopkins M. Measurement of corporate social responsibility. International Journal of Management and Decision Making. 2005;6(3).

[41] Verdeyen V, Put J, van Buggenhout B. A social stakeholder model. International Journal of Social Welfare. 2004;13(4):325-31.

[42] Groza MD, Pronschinske MR, Walker M. Perceived organizational motives and consumer responses to proactive and reactive CSR. Journal of Business Ethics. 2011;102(4):639-52.

[43] Petersen HL, Vredenburg H. Morals or economics? Institutional investor preferences for corporate social responsibility. Journal of Business Ethics. 2009;90(1):1.

[44] Kim H-R, Lee M, Lee H-T, Kim N-M. Corporate social responsibility and employee-company identification. Journal of Business Ethics. 2010;95(4):557-69.

[45] Wang YJ, Tsai YH, Lin CP. Modeling the relationship between perceived corporate citizenship and organizational commitment considering organizational trust as a moderator. Business Ethics: A European Review. 2013;22(2):218-33.

[46] Du S, Swaen V, Lindgreen A, Sen S. The roles of leadership styles in corporate social responsibility. Journal of business ethics 2013;114(1):155-69.

[47] Cohen E. CSR for HR: A necessary partnership for advancing responsible business practices: Routledge; 2017.

[48] Newman A, Miao Q, Hofman PS, Zhu CJ. The impact of socially responsible human resource management on employees' organizational citizenship behaviour: the mediating role of organizational identification. The International Journal of Human Resource Management. 2016;27(4):440-55. 
[49] Bučiūnienė I, Kazlauskaitė R. The linkage between HRM, CSR and performance outcomes. Baltic Journal of Management. 2012;7(1):5-24.

[50] BIEREMA LL, D'ABUNDO ML. HRD with a conscience: Practicing socially responsible HRD. International Journal of Lifelong Education. 2004;23(5):443-58.

[51] Garavan TN, McGuire D. Human resource development and society: Human resource development's role in embedding corporate social responsibility, sustainability, and ethics in organizations. Advances in Developing Human Resources. 2010;12(5):487-507.

[52] Greenwood M. Ethical analyses of HRM: A review and research agenda. Journal of Business Ethics. 2013;114(2):355-66.

[53] Shen J, Jiuhua Zhu C. Effects of socially responsible human resource management on employee organizational commitment. The International Journal of Human Resource Management. 2011;22(15):3020-35.

[54] Shen J, Benson J. When CSR is a social norm: How socially responsible human resource management affects employee work behavior. Journal of Management. 2016;42(6):1723-46.

[55] Orlitzky M, \& Swanson, D. L. Socially responsible human resource management. In J R Deckop (Ed), Human resource management ethics. 2006

[56] Carroll AB. Corporate social responsibility: Evolution of a definitional construct. Business \& society. 1999;38(3):268-95.

[57] O'brien D. Integrating corporate social responsibility with competitive strategy. The Center for Corporate Citizenship at Boston College. 2001:3-23.

[58] Pinkess A. Show you really care to win staff. Brand Strategy. 2008;224:38-9.

[59] Bhattacharya CB, Sen S, Korschun D. Using corporate social responsibility to win the war for talent. 2008. 